\title{
PARENTING PATTERNS FOR LEARNING DISCIPLINE OF ELEMENTARY SCHOOL CHILDREN IN LANGENHARJO VILLAGE, PATI
}

\author{
Asnafun Naimah ${ }^{1}$, Ika Oktavianti ${ }^{2}$, Muhammad Noor Ahsin $^{3}$ \\ ${ }^{1,2,3}$ Elementary Education Study Program, Universitas Muria Kudus, Indonesia
}

\begin{abstract}
Article Info
Article history:

Received: 04-02-2021

Revised: 15-07-2021

Published: 31-01-2022

Keywords:

Elementary School

Learning Discipline

Parenting Parenting

ABSTRACT

This study aims to analyze the role of parenting on the learning discipline of elementary school age children in Langenharjo Village, Margorejo District, Pati Regency. This research uses a qualitative case study method. The data collection technique used is data training or in the form of in-depth observations, interviews and documentation. The subjects studied were school students in Langenharjo Village and their parents. The data analysis technique used is data reduction, data presentation and conclusion drawing. The results showed that all parents provide a form of democratic parenting to their children. In the application of this parenting style, parents provide assistance and guide children in learning to apply discipline to children with full understanding. Parents also give freedom to children, but it must be accompanied by certain limits and rules for the good of the child which must be agreed upon by parents and children with various considerations and not burdensome to the child. Learning discipline, especially for children who attend SD Langenharjo 01, can be said to be going well, with democratic parenting applied by parents in dealing with learning conditions during a pandemic like this, students in studying and doing assignments can complete and collect assignments on time.
\end{abstract}

This is an open access article under the CC BY-SA license.

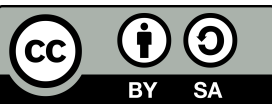

\section{Corresponding Author:}

Asnafun Naimah,

Elemetary Education Study Program, Universitas Muria Kudus

Jl. Lingkar Utara Kayuapu Kulon, Gondang Manis, Bae, Kudus, Indonesia

Email: asnafunnaimah@gmail.com

\section{INTRODUCTION}

Discipline is a process of training or learning that is related to the growth and development of children. In learning, self-discipline is a very strong foundation to train oneself and obey some rules in learning, in order to achieve the desired results (Juliansyah, 2021). Discipline in children is to provide an understanding of what is good and what is bad. Discipline education needs to be instilled in children that making mistakes certainly has a number of consequences, for that is the function of punishment in children's education. This is where the parenting style of parental responsibility is needed in shaping the discipline of children (Rofiah, 2015). However, when disciplining children, most parents consider discipline as something that is rigid so that it seems to force children to obey and obey their own responsibilities. Parents do not realize that discipline is a learning process that goes on all the time. On the good and bad of an achievement, it can affect a child's development, this is conveyed by (Kadir, 2008).

The formation of child discipline should be carried out by parents from an early age, where children are 
still very easy to give or direct to good things. The formation of discipline can be done through the participation of parents, where parents must know how to teach the right way to instill disciplined values in children without any element of coercion (Guimarães, Lemos, \& Nunes, 2011). Through parenting in instilling good discipline, a child will get used to doing things on a regular and scheduled basis. On the other hand, if children are not instilled or taught strong disciplinary behavior from an early age, then when they enter their teenage years, they will tend to find it difficult to develop a good and correct disciplinary attitude.

Learning during a pandemic like this does not require students to come to school. In fact, many schools enforce students to study using online methods or in the internet network for an indefinite time limit. Therefore, students need parental guidance and direction in carrying out learning. Not only that during a pandemic like now, parents are not only obliged to guide but parents are also obliged to care for, nurture and educate their children. However, every parent certainly has a different way of educating and raising their children. In line with the opinion expressed by Darmiany (2016), in the family has a great influence in shaping a character of discipline in children.

This study was conducted by examining the three parenting styles that each parent applies to their children in learning. In the opinion of Goldstein et al. (2017), there are three types of parenting styles, including authoritarian parenting, which is strict parenting or parents tend to force their children's will, democratic parenting is in this parenting parents give freedom to children and encouraging independence, and permissive parenting is parenting that frees children without parental control, but if children cannot control themselves, children can fall into negative things. Although now learning is done from home, of course the teacher also gives assignments to students to do at home with the guidance of their parents. With the assignment of course there is also an assessment. Students must work on assignments and then collect them to the teacher to be assessed.

\section{RESEARCH METHOD}

This research was conducted in Langenharjo Village, Margorego District, Pati Regency. Informants from this study were elementary school-aged children in Langenharjo Village, especially those who attended SD Negeri Langenharjo 1, SD Negeri Langenharjo 1 teachers and parents to analyze the role of parenting given to children with regard to children's learning discipline, especially during the pandemic Covid-19. This research was conducted with a qualitative approach using case study data analysis. According to Duflo \& Kiessel (2014), case study is a technique that investigates phenomena with context in real life. This research was conducted by prioritizing the depth of appreciation of the concepts studied empirically. This qualitative research was conducted by collecting data that researchers got from observations. Observations were made using nonparticipant observations to find out what was related to parenting patterns to motivate student learning. The interview technique used is an in-depth interview so that the data is obtained validly and has a high level of accuracy. The data obtained are in the form of observation notes, interview notes, field documentation, photographs and other supporting data and recording sheets. The data from the research were analyzed and presented in the form of a description so that the researcher would obtain objective data (Sugiyono, 2016). Qualitative data analysis was carried out during data collection and after data collection for a certain period. The validity test used triangulation technique as a data checking technique (Moleong, 2010). This can be achieved in the following ways: (1) Comparing the data from observations with the results of interviews; (2) Comparing one's situation and perspective with various opinions and views of others, other than parents and students; (3) Comparing the results of the interview with the contents of a related document. 


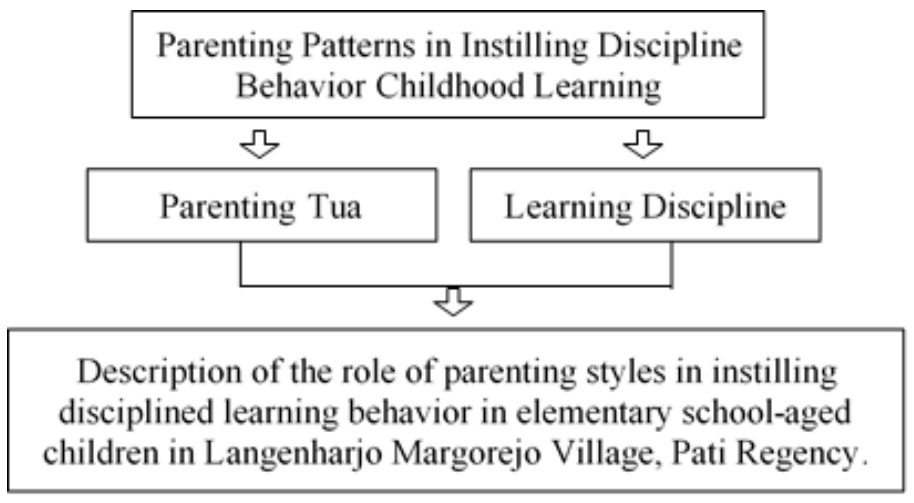

Figure 1. Mindset Chart

\section{RESULT AND DISCUSSION}

Table 1. Identity of Main Informants in Langenharjo Village

\begin{tabular}{lcll}
\hline No. & Name & Description & Address \\
\hline 1. & GRA & 4th Grade Student & Langenharjo RT. 05 RW. 02 \\
2. & KA & 4th Grade Student & Langenharjo RT. 01 RW. 01 \\
3. & MHK & 4th Grade Student & Langenharjo RT. 05 RW. 02 \\
4. & MHA & 4th Grade Student & Langenharjo RT. 01. RW. 02 \\
5. & ZSF & 4th Grade Student & Langenharjo RT. 05. RW. 02 \\
6. & SA & GRA's Parents & Langenharjo RT. 05 RW. 02 \\
7. & SRT & KA's Parents & Langenharjo RT. 01 RW. 01 \\
8. & IK & MHK's Parents & Langenharjo RT. 05 RW. 02 \\
9. & SC & MHA's Parents & Langenharjo RT. 01. RW. 02 \\
10. & ERY & ZSF's Parents & Langenharjo RT. 05. RW. 02 \\
11. & AS & Teacher at SDN 1 Langenharjo & Langenharjo RT. 03 RW.01 \\
\hline
\end{tabular}

\subsection{Parenting in Langenharjo Village}

Online learning caused by the Covid-19 pandemic, requires students to study at home. Therefore, the role of parents is needed in guiding children in learning. This is supported by the opinion of Hamalik (2008), who said that parents must have an important role in terms of learning progress and responsibility in doing the tasks that students have. Especially in doing assignments, of course, must be done on time, therefore student learning discipline is needed. Parenting patterns are needed in instilling student learning discipline so that students can study well.

Parenting is a reciprocal relationship between parents and children with the process of educating, guiding, and disciplining children to reach maturity to become independent. According to O'Connor \& Scott (2007), Parenting itself is divided into three types, namely authoritarian parenting, this parenting tends to be harsh and imposes the will of the child, democratic parenting is a parenting pattern that provides freedom with parental control so that children are encouraged to be independent. , and permissive parenting is parenting that frees children without parental control.

The results of the study show that parents provide assistance to children in conducting online learning to do assignments so that they are on time. Parents provide assistance to children starting when the child will prepare learning activities. Parents wake their children up before learning hours start to prepare in advance so that their children are on time for attending. Children learn online and do the assignments given by the teacher with the assistance of their parents. Parents also check the children in collecting the assignments given by the teacher so that they are on time. Parents provide assistance to children so that children are motivated to carry out the habits taught by parents so that children can apply disciplined behavior in learning. Therefore, parenting is very much needed by children from an early age in instilling student learning discipline. In these conditions, the teacher gives assignments to students online.

During the implementation of online learning, the limited guidance from the teacher makes learning less effective. Learning carried out at home emphasizes that parents play an active role in carrying out learning, 
so that learning done at home can run according to the schedule determined by the school. Limited time and place are not a barrier for students to do learning. Every morning students are required to take lessons online, students' study from home while the teacher continues to give assignments to students. The role of parenting in guiding children in disciplining student learning is very much needed because student discipline in doing assignments is very necessary, especially when learning is carried out at students' homes, each teacher cannot guide as a whole as usual learning is done at school (Maja, Nurhasanah, \& Husniati, 2021).

Based on the results of research that has been carried out in Langenharjo Village, there are students who are conducting online learning activities, this can be proven when conducting research which states that researchers see firsthand the situation when students are learning and doing assignments online with the guidance of parents who have a background and different jobs. Judging from the results of the study, although parents still do not really understand the parenting provided, and different background conditions and busyness, parents are still aware of their responsibility to accompany and guide their children in controlling children's learning activities.

Moreover, parents are busy working, parents who have formal jobs are bound by working hours so that they have less time to control their children. Meanwhile, parents who have informal jobs or own businesses, tend to be busy with their work in facing business competition so that their businesses are more advanced. This is supported by the opinion if parents are too free of their children on the grounds that parents are busy with their own business, so that children become less attentive and do negative things to get attention. The intensity of the interaction between parents and children in this condition greatly affects the learning discipline of children, the results of this study are in line with the statement from Sunarti (2004), that parenting patterns with less intensive interactions between parents and children provide direction that is not good, so that the child's discipline becomes less than optimal (Nyoman, Astuti, Setiawan, \& Mataram, 2021).

It can be seen that parents of SD Langenharjo 01 students apply democratic parenting in giving attention to children in socializing and socializing seen in parents giving freedom to children accompanied by certain rules and restrictions, which can affect the child's personality. This condition is supported by the statement according to Aguiar et al. (2019), that democratic parenting tends to provide opportunities for children and the freedom to behave according to age according to what they want. In addition, parents also give freedom to choose which ones are good and which are not good because this also affects the development of children. Children are also given freedom with responsibility and control from parents.

\subsection{Children's Learning Discipline Behavior in Langenharjo Village}

Based on the results of research conducted in Langenharjo Village on student learning discipline behavior, in carrying out learning activities children must have learning discipline behavior that is owned by every student. In the behavior of student learning discipline that differs from one student to another, learning discipline is the most important thing for students to be able to control themselves and make behavior to be able to learn to be even better. As explained by Cláudia Rodrigues Sequeira de Figueiredo \& Filomena Valadão Dias (2012), learning discipline teaches children to have good self-control limits, obey the rules at school, general rules everywhere can develop good habits and control themselves.

Student learning discipline behavior is divided into 3 categories, namely the first discipline in relation to study time, the second discipline related to the place of study, and the third discipline related to norms and rules in learning. This category of learning discipline is not paid much attention to by parents or teachers because learning discipline itself appears naturally which is done by children when carrying out learning activities with parents at home, so parents can set an example for their children with regard to discipline using democratic parenting. This is supported by a statement from Ahmadi (2007), that the attitude of behavior with the habits of parents every day is always seen and unconsciously will become a habit of the child's behavior.

Even with this situation, parents are still aware of their responsibility to keep trying to accompany their children's learning so that they remain maximal in carrying out learning and collecting assignments. An explanation of student learning discipline in Langenharjo Village is as follows:

\subsubsection{Discipline in relation to study time}

In carrying out activities at school and at home, students must carry out learning on time, students can collect assignments and study according to a set schedule. By carrying out learning well, the learning carried out will run optimally and have a positive influence. This condition is supported by Flinn \& England (1995), statement which states that the discipline of cooperation is an open relationship between two or more individuals with responsibility. 


\subsubsection{Discipline in Relation to the Place of Study}

In disciplinary behavior, students are not only disciplined with study time but also disciplined with the place of study. This statement was also conveyed Nalon et al. (2018), discipline related to learning time, discipline related to the place of study, and discipline related to norms and rules in learning. In the discipline of learning, namely the development of behavior that is limited in a certain rule. Learning discipline is related to the place of study aimed at being able to discipline student learning. As emphasized by Gross \& Rutland (2017), that a good and comfortable atmosphere at home also helps students interested in learning, such as a supportive learning place, the response of students who answered that a comfortable place can affect students' interest in learning.

\subsubsection{Discipline in Relation to Learning Norms and Rules}

In learning children have rules that must be obeyed. Not only learning at school has rules, but at home also has rules. Education is not only done at school, but can also be done in the family environment. With education in the family environment is also the main point in gaining knowledge. According to Yazar Soyad (Yazar Soyad, 2015) explain that discipline is a rule that must be implemented and mutually agreed upon so it is very important to do it since childhood as possible in order to behave according to the rules. So that children have rules that must be obeyed and are responsible for their duties.

\section{CONCLUSION}

The parenting style applied by parents to students in Langenharjo Village is more democratic. In the application of this parenting style, parents provide assistance and guide children in learning to apply discipline to children with full understanding. Parents also give freedom to children, but it must be accompanied by certain limits and rules for the good of the child which must be agreed upon by parents and children with various considerations and not burdensome to the child. Learning discipline, especially for children who attend SD Langenharjo 01, can be said to be going well, with democratic parenting applied by parents in dealing with learning conditions during a pandemic like this, students in studying and doing assignments can complete and collect assignments on time. . Children can study in various places and clean the learning area before learning. Children also seem to have rules in online learning, children obey orders and listen to parents' advice and do not violate the rules agreed upon by parents and children. In learning, children also have good responsibility for tasks by working with self-awareness and being able to complete and collect assignments on time. Thus, it can be said that the role of parents in the learning discipline of elementary school-aged children in Langenharjo Village is very important and has a great influence on learning in elementary schools.

\section{REFERENCES}

Aguiar, A. L., Aguiar, C., Cadima, J., Correia, N., \& Fialho, M. (2019). Classroom quality and children's social skills and problem behaviors: Dosage and disability status as moderators. Early Childhood Research Quarterly, 49, 81-92. doi:10.1016/j.ecresq.2019.05.005

Ahmadi, A. (2007). Psikologi Sosial. Jakarta: PT Rineka Cipta.

Anik Darmiany. (2016). PENGEMBANGAN MODEL PELATIHAN SOFT-SKILLS PADA SISWA SEKOLAH MENENGAH PERTAMA NEGERI (SMPN) DI KOTA MATARA. Jurnal Kajian Bimbingan dan Konseling, 1(2), 47-54.

Cláudia Rodrigues Sequeira de Figueiredo, \& Filomena Valadão Dias. (2012). Families: Influences in Children's Development and Behaviour, From Parents and Teachers' Point of View. Journal of Psychology Research, 2(12), 693-705. doi:10.17265/2159-5542/2012.12.001

Duflo, A., \& Kiessel, J. (2014). Every Child Can, Every Child Counts: An evaluation of the Teacher Community Assistant Initiative (TCAI) Pilot Programme in Ghana. Innovations for Poverty Action (IPA), l(March), $1-27$.

Flinn, M. V., \& England, B. G. (1995). Childhood Stress and Family Environment. doi:10.1086/204444

Goldstein, M., Crowell, A., \& Kuhn, D. (2017). What Constitutes Skilled Argumentation and How Does it Develop? Informal Logic, 29(4), 379. doi:10.22329/il.v29i4.2905

Gross, Z., \& Rutland, S. D. (2017). Experiential learning in informal educational settings. International Revolution Education, 6(3), 1-9. doi:10.1007/s1115901796256 
Guimarães, S., Lemos, I., \& Nunes, C. (2011). Social Skills and Academic Achievement of Adolescent Immigrants in School Settings. International Journal of Developmental and Educational Psychology, 1, $115-120$.

Hamalik, O. (2008). Perencanaan Pengajaran Berdasarkan Pendekatan Sistem. Jakarta: Bumi Aksara.

Juliansyah, A. (2021). HUBUNGAN KOMUNIKASI DALAM KELUARGA TERHADAP MOTIVASI BELAJAR PESERTA DIDIK KELAS IV SDN GUGUS 02 KECAMATAN ALAS COMMUNICATION RELATIONSHIP WITH THE FAMILY TO THE LEARNING MOTIVATION OF CLASS IV STUDENTS OF SDN GUGUS 02 KECAMATAN ALAS IN ACADEMIC YEAR 2019. Renjana Pendiidkan Dasar, 1(1), 23-29.

Kadir. (2008). Kemampuan Komunikasi Matematik Dan Keterampilan Sosial Siswa Dalam Pembelajaran Matematika. In Seminar nasional matematika dan pendidikan matematika (pp. 339-350). Yogyakarta: Jurusan Pendidikan Matematika FMIPA UNY.

Maja, C. M. A., Nurhasanah, \& Husniati. (2021). PENGARUH METODE GROUP INVESTIGATION TERHADAP AKTIVITAS BELAJAR MUATAN IPS SISWA KELAS IV SDN 3 SAMBELIA TAHUN THE INFLUENCE OF GROUP INVESTIGATION METHODS ON THE LEARNING ACTIVITIES OF CLASS IV STUDENTS OF SDN 3 SAMBELIA IN THE ACADEMIC YEAR 2020 / 2021. Renjana Pendiidkan Dasar, 1(1), 16-22.

Moleong, L. J. (2010). Metodologi Penelitian Kualitatif. Bandung: PT Remaja Rosdakarya.

Nalon, G. H., Barbosa, P. S. d. A., \& Nascimento, W. D. (2018). Educational digital resource for data analysis of Civil Engineering laboratory tests. Modelling in Science Education and Learning, 11(1), 43. doi:10. 4995/msel.2018.9140

Nyoman, N., Astuti, S., Setiawan, H., \& Mataram, U. (2021). Pengaruh Model Concept Sentence Berbantuan Flash Card Correlation of Teacher Personality Competence With Discipline of Student Learning in Grade 5 At Sd Negeri Gugus I Lopok Academic Year 2020 / 2021. Renjana Pendidikan Dasar, 1(1), 35-43.

O’Connor, T., \& Scott, S. (2007). Parenting and outcomes for children. Joseph Rowntree Fondation, 14(1), 47-67.

Rofiah, N. H. (2015). Proses identifikasi: Mengenal anak kesulitan belajar tipe disleksia bagi guru sekolah dasar inklusi. INKLUSI, 2(1), 109. doi:10.14421/ijds.020110

Sugiyono. (2016). Metode penelitian kuantitatif kualitatif dan $R \& D$. Bandung: Alfa Beta.

Sunarti, E. (2004). Mengasuh dengan Hati Tantangan yang Menyenangkan. Jakarta: Elex Media Komputindo.

Yazar Soyad,, M. L. (2015). Golden Age or Harmful Obsession Policy and Practice of Gifted and Talented Education in England 1997-2008. Journal for the Education of Gifted Young Scientists, 3(2), 51-51. doi:10.17478/JEGYS.2015214278 